\title{
Camille Flammarion's observatory: towards a revival
}

\author{
P. Morel, J.C. Pecker, A. Flammarion, P. Fuentes, C.A. Stépanoff, \\ R. Sol, G. Dufour, R. Chaufour \& J. Goury-Laffont
}

Société Astronomique de France

3 Rue Beethoven, 76016 Paris, France

email: morel.philippe@wanadoo.fr

\begin{abstract}
Camille Flammarion's observatory, located in Juvisy-sur-Orge in the suburbs of Paris, has been idle since 1962. Property of the Société Astronomique de France (SAF), it was made available to the city of Juvisy-sur-Orge since 1971, and contains a unique collection of objects and books currently being sorted out. The observatory is being restored by the SAF, thanks to the support of the city of Juvisy-sur-Orge, the French Académie des Sciences and the "Amis de Camille Flammarion" association. In 2006, the Maxime Goury Laffont foundation funded the refurbishment of the $240 \mathrm{~mm}$ refractor and in 2007 funds were obtained to restore the dome and central building. The main aim of the project is to make this historical place a popular observatory dedicated to astronomy and the sciences which Camille Flammarion enjoyed and contributed to. It constitutes a unique example in France of synergies linking associations, municipality, regional- and national-level institutions.
\end{abstract}

Keywords. observatories, heritage, Flammarion

\section{The observatory of Camille Flammarion}

Camille Flammarion, born in 1842, was 40 when he became the owner of the site that will become his observatory at Juvisy-sur-Orge. It will take him 12 years to transform the old inn into an observatory worthy of the greatest institutions of the time. In 1887, the dome built by the Gillon company and the $240 \mathrm{~mm}$ diameter refractor built by Bardou were inaugurated by the emperor of Brazil Dom Pedro II of Alcântara. It is also the year of the foundation of the Société Astronomique de France by Camille Flammarion.

The observatory carried out an intense astronomical activity and had as employees astronomers such as Eugene Antoniadi from 1893 to 1902 and Ferdinand Quénisset until his death in 1951. Camille Flammarion passed away on June 3, 1925 and his wife Gabrielle continued his legacy for 37 years. She died in 1962.

The Société Astronomique de France inherited the observatory and Camille Flammarion's collections. The observatory was not going to be inhabited any longer. Since 1972, the park and the first two levels of the observatory are conceded with the municipality of Juvisy-sur-Orge by an emphyteutic lease of 99 years and repairing obligation of the conceded goods. In 2002 the SAF approached the municipality of Juvisy-sur-Orge to enquire on possible funds, but was told to bring the funds!

In 2004 the local association "Friends of Camille Flammarion" is founded by taxpaying voters living in Juvisy-sur-Orge. A petition gathering more than 2,000 signatures made the municipality change its attitude. 


\section{The revival}

In 2006, the SAF received a gift from the Foundation Maxime Goury Laffont for the restoration of the refracting telescope. This gift is supplemented by funds from the French ministry of culture. The Municipality of Juvisy-sur-Orge approaches the SAF to contribute. On June 2, 2007 in the presence of the historian of sciences Owen Gingerich, the refractor leaves the dome which sheltered it during 122 years for two years of restoration by the TRASSUD company. A committee is set up which includes representatives of the Juvisy-sur-Orge municipality, the SAF and the association Les Amis de Camille Flammarion. A strategy for the public financing of the first part of the restoration is elaboated. The Municipality of Juvisy-sur-Orge even becomes member of the SAF.

Following contacts established by the SAF with the deputy of the district of Juvisysur-Orge, Jean Marsaudon, a fund of $100,000 €$ is voted by the National Assembly in May 2008. A few days later, all the other necessary financings for the restoration of the dome and the central part of the building are approved. At the end of the IYA in 2009, the telescope thus finds its place under an entirely restored dome: the activities of the observatory are expecte to resume by the end of 2010 .

\section{The future}

The project includes showrooms in the main floor, a museum at the first floor, a library with the invaluable books at the second floor and an access of the dome for the public.

The Ducastel building, property of the Municipality of Juvisy, located just besides the observatory will be the welcoming hall for visitors and also a conference room. By this building the new tram station "Observatoire" will be erected, providing an easy access.

In the park an astronomical walk will be set up and will include full-scale models of the most remarkable historical astronomical instruments. Several telescopes will be used for public observations. The observatory will be open to all and will be a place unique in France where both historical and cultural heritage will be used for the diffusion of science. 